\title{
Photovoltaic Based Vapour Compression Refrigeration System for Vaccine Preservation
}

\author{
S. R. Kalbande ${ }^{1, *}$, Sneha Deshmukh ${ }^{2}$ \\ ${ }^{1}$ Faculty of Agricultural Engineering, Dr. Panjabrao Deshmukh Krishi Vidyapeeth, India
${ }^{2}$ Department of Unconventional Energy Sources and Electrical Engineering, Dr. Panjabrao Deshmukh Krishi Vidyapeeth, India
}

Copyright $@ 2015$ Horizon Research Publishing All rights reserved.

\begin{abstract}
The performance evaluation of photovoltaic based vapour compression refrigeration system was carried out in the Department of Unconventional Energy Sources and Electrical Engineering, Dr. PDKV Akola. The DC refrigerator was powered by a field of solar panels, a battery bank, and a solar charge controller. It was observed that the energy consumption of a photovoltaic operated vapour compression refrigerator was typically 429 - $660 \mathrm{~W}$ per day for recommended storage condition of vaccines $\left(2-8^{\circ} \mathrm{C}\right)$. The performance of thermoelectric refrigerator had found impact of ambient temperature on its performance in terms of cooling effect and power consumption which was more than the vapour compression refrigerator. The output power of the photovoltaic system was determined at no load and full load conditions. The experimental data were used for the calculation of the energy and exergy efficiencies of the PV systems. The average photovoltaic efficiency was found to be 8.4 and $8.2 \%$ for no load and full load conditions while energy efficiency was 11.4 and $11.2 \%$, respectively Multiple regression analysis carried out to predict the power output, photovoltaic efficiency and exergy efficiency and showed significant results.
\end{abstract}

Keywords Solar Photovoltaic, Vapor Compression Refrigeration, Thermoelectric Refrigerator, Exergy Efficiency, Photovoltaic Efficiency

\section{Introduction}

Due to the growing concern and awareness of environmental issues among the scientific community, power generation from renewable energy sources, particularly solar energy has become significantly important for the last few decades. The energy efficiency of a solar panel, the ratio of the power output to the energy originally delivered to the solar panel, conventionally is used to measure solar PV efficiency. Energy analysis is based primarily on the first law of thermodynamics, as compared with exergy analysis which is based on the second law.
Energy analysis is concerned only with the quantity of energy use and efficiency of energy processes. Energy analysis thus ignores reductions of energy potential, which could be used productively in other physical and/or chemical process. Energy analysis can provide sound management guidance in those applications in which usage effectiveness depends solely on energy quantities.

Exergy analysis is used to find out the energy utilization efficiency of an energy conversion system. Exergy analysis yields useful results because it deals with irreversibility minimization or maximum exergy delivery. The exergy analysis has been increasingly applied over the last several decades largely because of its advantages over energy analysis. To perform energy and exergy analyses of the solar PV, the quantities of input and output of energy and exergy must be evaluated.

\section{Literature Reviewed}

Some researchers conducted experiments on the performance analysis of photovoltaic driven vapour compressor refrigeration system. Kattakayam et al. (1996) studied the electrical characteristics of a $100 \mathrm{~W}$ AC operated domestic refrigerator using R-12 powered by a field of SPV panels, a battery bank and an inverter. A minimum current region was observed in the mains voltage range of 180-190 $\mathrm{V}$ and at the inverter voltage range of 210-230 V. Charters and Oo (2003) suggested its use in developing countries for essential purposes such as vaccine serum storage at medical clinics in remote regions. Eltawil and Samuel (2007) stated that refrigerated storage, was believed to be best method for storing the fruits and vegetables in fresh form, which were not available in rural or remote locations where grid electricity was almost not available. Fatehmulla et al. (2011) designed and developed low power refrigeration system using PV modules, 2 modules each of 36 solar cells. Yilanci et al. (2011) studied the energy an analysis of a refrigerator, powered by a photovoltaic investigated to obtain efficient operation conditions based on experimental data. Sobamowo et al. (2012) designed and developed photovoltaic-powered 
dc vapour compression refrigeration system for developing countries such as Nigeria and showed that its applicability to different climatic regions in Africa and could be used for perishable food storage, improvement in the health services and living conditions in remote and rural areas which were unable to access electricity from the grid.

\section{Material and Methods}

In this experimental study, the comparative energetic and exegetics analysis of solar photovoltaic (SPV) modules has been carried out for a March, April and May month under the different climatic conditions.

\subsection{Experimental System}

A SPV refrigeration system consisted of DC vapor compression refrigerator of 25 litre capacity. Considering the power requirement of its continuous operation, two 80 W SPV panels were used to convert solar energy into electrical energy. The panels were arranged in parallel. The purpose of this arrangement was to have sufficient potential difference across the $12 \mathrm{~V}$ battery for properly charging of battery. The panels were kept on fixed masonry structure at $35^{\circ}$ (tilt angle) from horizontal, facing south direction. A battery was used so that it could give high starting current required to start the motor of compressor. It consisted of one $12 \mathrm{~V}$ - 150 Ah sealed lead batteries connected in parallel. Panel was connected to the battery via charge controller which avoided the battery from deep discharge. Battery supplied DC current to refrigerator as it operated on DC current.

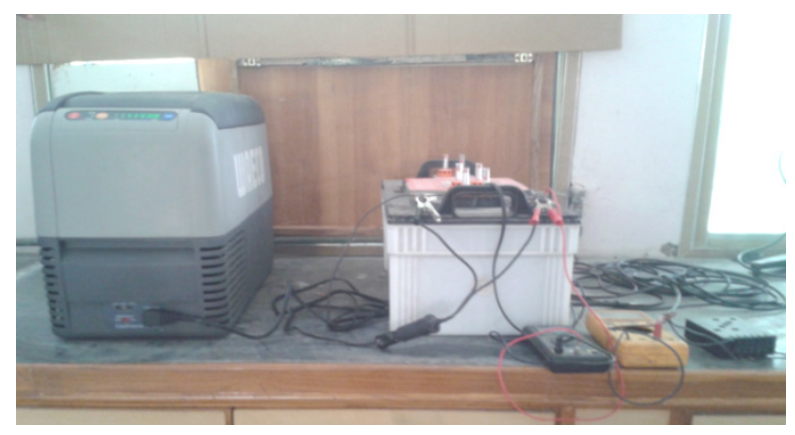

Figure 1. Experimental setup of the experiment

\subsection{Energy Efficiency of the Solar Panel}

\section{Photovoltaic Efficiency}

The efficiency of the solar panels, defined as the ratio of the electrical power produced to the incident radiation. Photovoltaic efficiency of solar panel was determined at no load and full load condition by using following formula.

$$
\eta_{p v}=\frac{P_{\max }}{S \times A_{p v}}
$$

Where, $\eta_{p v}=$ Efficiency of photovoltaic system
$\mathrm{P}_{\max }=$ Maximum power from photovoltaic system (W)

$\mathrm{S}=$ Solar irradiance $\left(\mathrm{W} / \mathrm{m}^{2}\right)$

$A_{p v}=$ Area of the photovoltaic system $\left(\mathrm{m}^{2}\right)$

\section{Exergy Analysis}

Exergy is defined as the maximum amount of work that can be done by a system.

\section{Photovoltaic Exergy}

The energy of a PV module depends on two major components--electrical and thermal.

$$
E x_{\text {out }}=V_{m} I_{m}-\left(1-\frac{T_{0}}{T_{\text {cell }}}\right)\left[h_{c} \times A_{p v}\left(T_{\text {cell }}-T_{o}\right)\right]
$$

Where $\mathrm{V}_{\mathrm{m}}, \mathrm{I}_{\mathrm{m}}, h_{\mathrm{c}}, A, T_{\text {cell }}$ and $T_{\mathrm{o}}$ are the maximum voltage and current of the photovoltaic system, convective heat transfer coefficient from the photovoltaic cell to ambient, area of the photovoltaic surface, cell temperature and ambient temperature (dead state temperature), respectively.

The convective heat transfer coefficient from the photovoltaic cell to ambient can be calculated by using correlation

$$
h_{c}=5.7+3.8 \times v
$$

Where, $\mathrm{v}=$ Wind velocity $(\mathrm{m})$

The cell temperature can be determined by the following relationship:

$$
\begin{aligned}
& T_{\text {cell }}=0.943 T_{a}+0.028 \text { Irradiance }- \\
& 1.528 \text { Windspeed }+4.3
\end{aligned}
$$

Exergy input of the photovoltaic system, which is the exergy of solar energy, can be calculated approximately as below

$$
\begin{gathered}
E x_{\text {in }}=E x_{\text {solar }}=A_{p v} \times S \times\left[1-\frac{4}{3}\left(\frac{T_{o}}{T_{S U N}}\right)+\right. \\
\left.\frac{1}{3}\left(\frac{T_{o}}{T_{S U N}}\right)^{4}\right]
\end{gathered}
$$

Where, $\mathrm{T}_{\mathrm{SUN}}=$ Temperature of the Sun taken as $5760{ }^{\circ} \mathrm{K}$

Exergy efficiency of the photovoltaic system is defined as the ratio of total output exergy (recovered) to total input exergy (supplied). It can be expressed as

$$
\psi_{\mathrm{PV}}=\frac{\mathrm{Ex}_{\mathrm{out}}}{\mathrm{Ex}_{\mathrm{in}}}
$$

\section{Statistical Analysis}

Multiple regression analysis is used to investigate the relationships between a dependent variable (photovoltaic efficiency, exergy efficiency and power output) and a set of independent variables( solar radiation, ambient temperature). Multiple regression equations were used to predict the photovoltaic efficiency, exergy efficiency and power output from photovoltaic system. Surface response analysis for April month was carried out.

\section{Result and Discussion}

\subsection{Performance Evaluation of Photovoltaic System at no Load}


The performance of the photovoltaic system was evaluated in terms of photovoltaic energy and exergy efficiencies during no load testing. Solar intensity was measured hourly and the open circuit voltage and short circuit current was measured during the off cycle of the refrigeration system.

The hourly variation of conversion efficiency $\left(\eta_{\bmod }\right)$ is illustrated in figures 3.1, 3.2 and 3.3. It is clear from the figure that the efficiency was relatively higher during the early and late hours of the day as compared to midday which was due to thermal effects. It was found that, the conversion efficiency is inversely proportional to the module temperature. The photovoltaic efficiency was found in the range of 7.48 to $10.14 \%$. The average efficiency of the photovoltaic system was observed $8.46 \%$ for May month. The average photovoltaic efficiency was 9.93 and $8.5 \%$ for March and April months, respectively.

At maximum solar radiation, difference between exergy in and out was found more. The exergy in was maximum due to more temperature which is due to more solar radiation. Increased PV array temperature determines the sensible decrease of this efficiency. In order to have maximum exergy efficiency, PV array temperature should be kept near the ambient temperature or in other words, PV array temperature should be controlled. Exergy efficiency was found to be $8.26 \%$ at $13 \mathrm{~h}$ due to increase in cell temperature $\left(56.11^{\circ} \mathrm{C}\right)$ with maximum solar intensity of $911.90 \mathrm{~W} / \mathrm{m}^{2}$.Exergy efficiency was determined to be $19.15 \%$ at $17 \mathrm{~h}$ due to less cell temperature $\left(35.9^{\circ} \mathrm{C}\right)$. Average exergy efficiency was found to be $11.41 \%$. Average exergy efficiency for March and April month were 13.02 and $12.18 \%$.

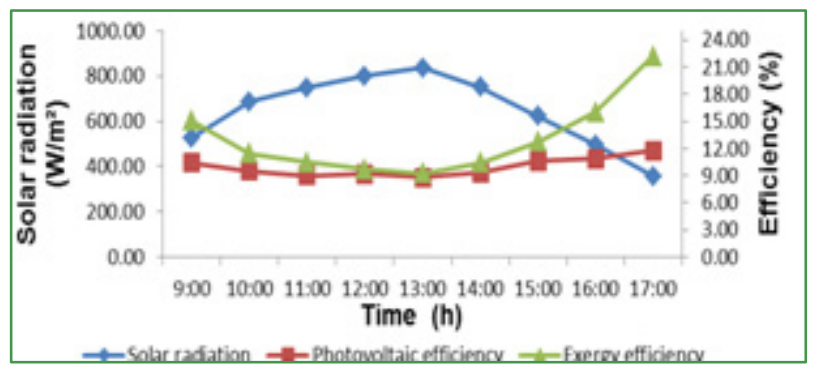

Figure 2. Variation of photovoltaic efficiency, exergy efficiency and solar radiation with time (March)

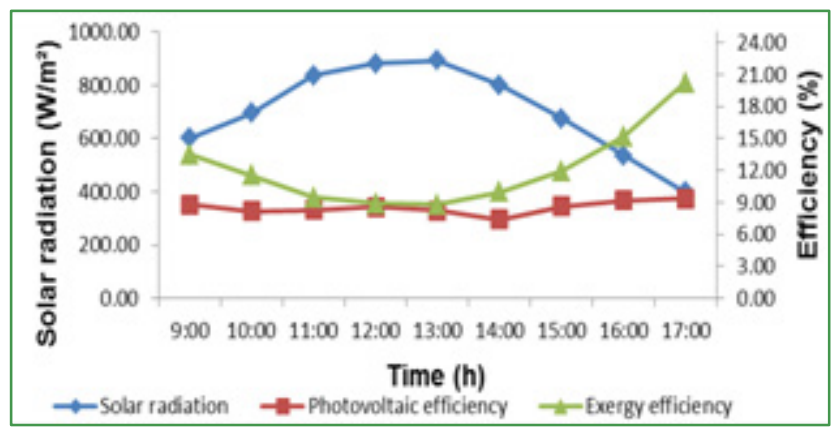

Figure 3. Variation of photovoltaic efficiency, exergy efficiency and solar radiation with time (April)

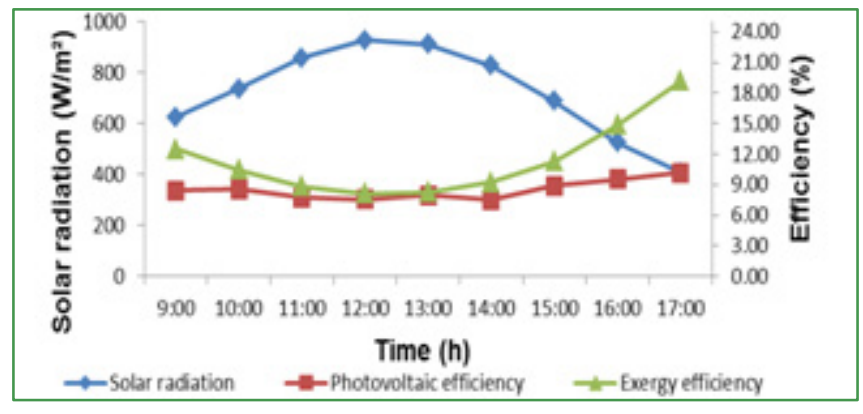

Figure 4. Variation of photovoltaic efficiency, exergy efficiency and solar radiation with time (May)

Multiple regression equations were obtained and used to predict the photovoltaic efficiency, exergy efficiency and power output with load. Following multiple regression equation used to predict the module efficiency of May month:

$\eta_{\mathrm{pv}}=9.5555-0.0052 \mathrm{SR}+0.0640 \mathrm{~T}_{0} \quad \mathrm{R}^{2}=0.89$

Where, $\mathrm{SR}-$ Solar radiation $\mathrm{T}_{0}$ - ambient temperature

$\Psi_{\mathrm{PV}}=20.3278-0.0206 \mathrm{SR}+0.1420 \mathrm{~T}_{0} \quad \mathrm{R}^{2}=0.95 \mathrm{P}_{\text {output }}$

$=18.7411+0.0752 \mathrm{SR}+0.3131 \mathrm{~T}_{0} \quad \mathrm{R}^{2}=0.94$

Several multiple regression equations were obtained for March and April month also. It was concluded that there is variation in photovoltaic efficiency, exergy efficiency and power output. Solar radiation and ambient temperature significantly affect the both efficiencies and power output.

\section{Performance evaluation of photovoltaic system at full load}

From figure 3.6 it is observed that photovoltaic efficiency found $(8.24 \%)$ highest in early morning and $10.02 \%$ in afternoon at $17.00 \mathrm{~h}$ with corresponding solar radiation of 627.00 and $424.80 \mathrm{~W} / \mathrm{m}^{2}$, respectively. Thus it was affected by solar radiation and module temperature. The average photovoltaic efficiency was found to be $8.2 \%$ for May month. The average photovoltaic efficiency for March and April month were 9.74 and $8.36 \%$, respectively.

The performance of photovoltaic system was evaluated at full load condition by adopting the same procedure as adopted in no load condition. From figures it can be easily seen that the exergy-in of sun was maximum of about 1258.22 W indicated the great potential of sun to emit power and it increased with increase in solar radiation. It was analyzed and shown in the figure that the photovoltaic exergy-out found $99.58 \mathrm{~W}$ found below the maximum power extract from the photovoltaic system due to the high cell temperature produced heat energy and this heat energy being lost by the system. The exergy efficiency was found to be $18.31 \%$ at cell temperature $37.74^{\circ} \mathrm{C}$ at solar radiation of $424.80 \mathrm{~W} / \mathrm{m}^{2}$. At $13.00 \mathrm{~h}$ the exergy efficiency found minimum $(7.9 \%)$ at cell temperature of $56.97^{\circ} \mathrm{C}$ and solar radiation $943 \mathrm{~W} / \mathrm{m}^{2}$ for May month. The average exergy efficiency was found to be $13.02,12.18$ and $11.11 \%$ for March, April and May month, respectively.

Figure showed the exergy of the radiation incident on the inclined plane, i.e., the maximum electrical power 
obtainable from the radiation, and the power supplied by the photovoltaic modules. The figure showed the influence of the battery charge controller on the efficiency of the photovoltaic modules.

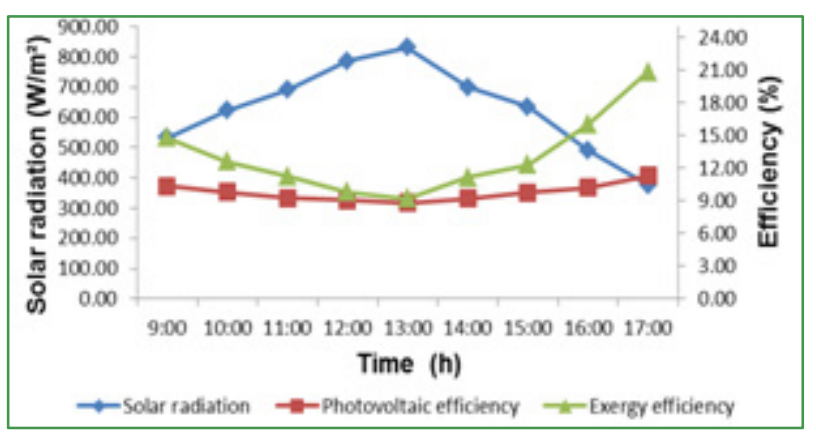

Figure 5. Variation of photovoltaic efficiency, exergy efficiency and solar radiation with time (March)

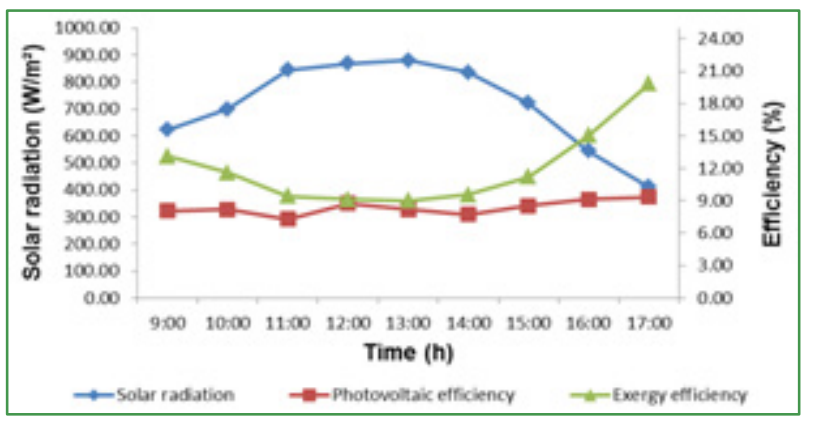

Figure 6. Variation of photovoltaic efficiency, exergy efficiency and solar radiation with time (April)

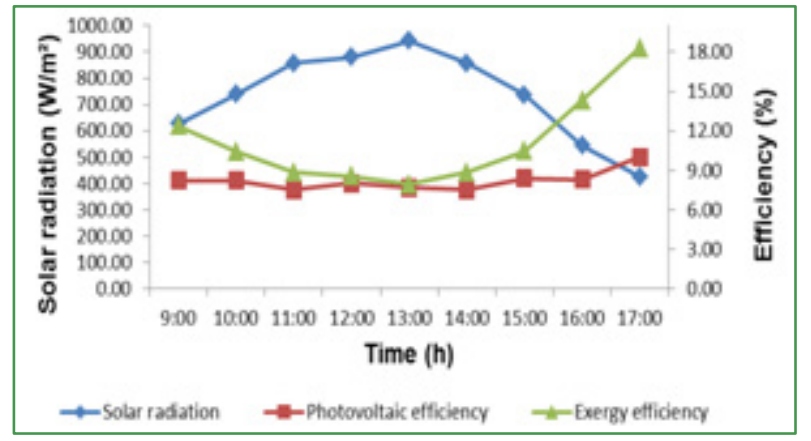

Figure 7. Variation of photovoltaic efficiency, exergy efficiency and solar radiation with time (May)

Multiple regression equations were obtained and used to predict the module efficiency, exergy efficiency and power output with load for May month. The regression equation for photovoltaic efficiency is as follows:

$$
\begin{array}{ll}
\eta_{\mathrm{pv}}=4.8542-0.0057 \mathrm{SR}+0.1772 \mathrm{~T}_{0} & \mathrm{R}^{2}=0.87 \\
\psi_{\mathrm{PV}}=24.7071-0.0193 \mathrm{SR}+0.0151 \mathrm{~T}_{0} & \mathrm{R}^{2}=0.95 \\
\mathrm{P}_{\text {output }}=36.2403+0.0930 \mathrm{SR}-0.4488 \mathrm{~T}_{0} & \mathrm{R}^{2}=0.96
\end{array}
$$

Analysis of data indicated that power ouput was significant at $1 \%$ level of significance and solar intensity and ambient temperature was highly significant and affected the SPV power output and significant results were observed for March and April month.

Performance of photovoltaic system evaluated by surface response analysis for April month at no load and full load condition and same results were obtained according this analysis.
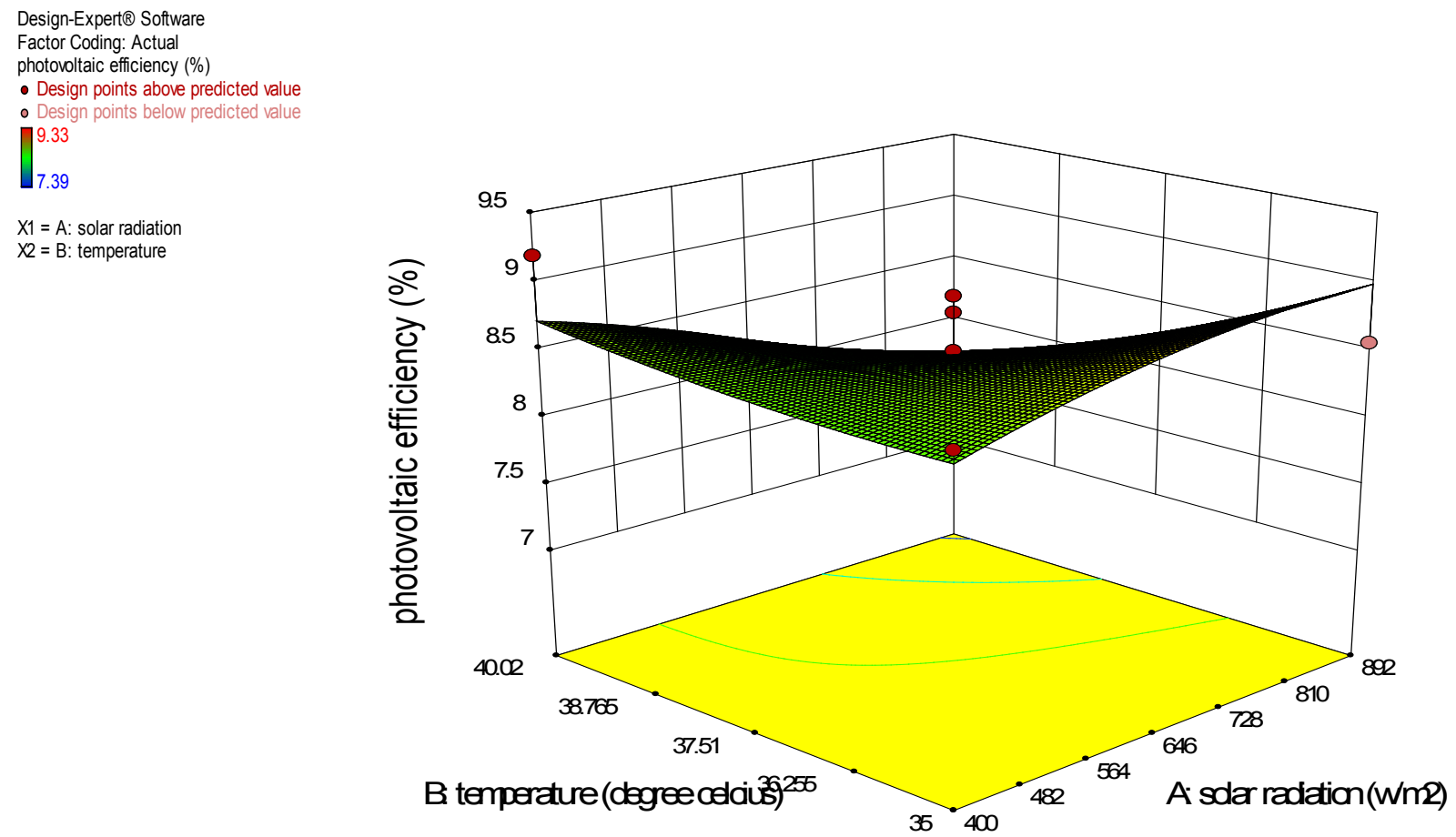

Figure 8. Analysis of photovoltaic efficiency with respect to solar radiation and temperature at no load (April) 
Design-Expert@ Software Factor Coding: Actual
exergy efficiency (\%)

exergy efficiency (\%)

-20.26
-2019

8.81

$\mathrm{X} 1=\mathrm{A}$ : solar radiation

$\mathrm{X}_{2}=\mathrm{B}:$ temperature

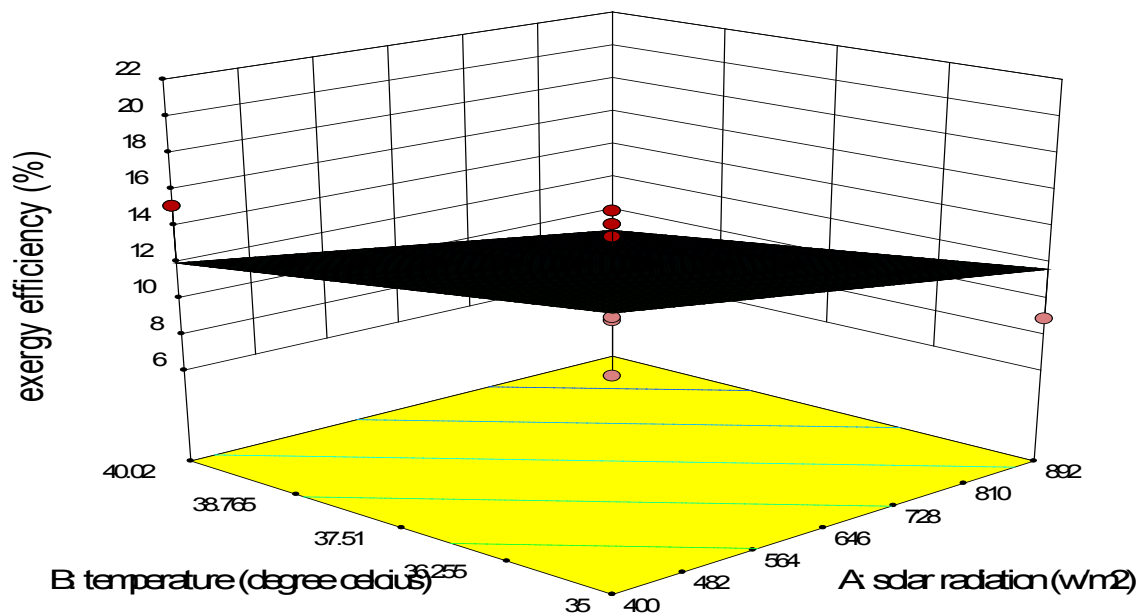

Figure 9. Analysis of exergy efficiency with respect to solar radiation and temperature at no load (April)
Design-Expert $\circledast$ Software

Factor Coding: Actual

photovoltaic efficiency (\%)

- Design points above predicted value

- Design points below predicfed value

T.35

7.31

$\mathrm{X} 1=\mathrm{A}:$ solar radiation $\mathrm{X} 2=\mathrm{B}:$ temerature

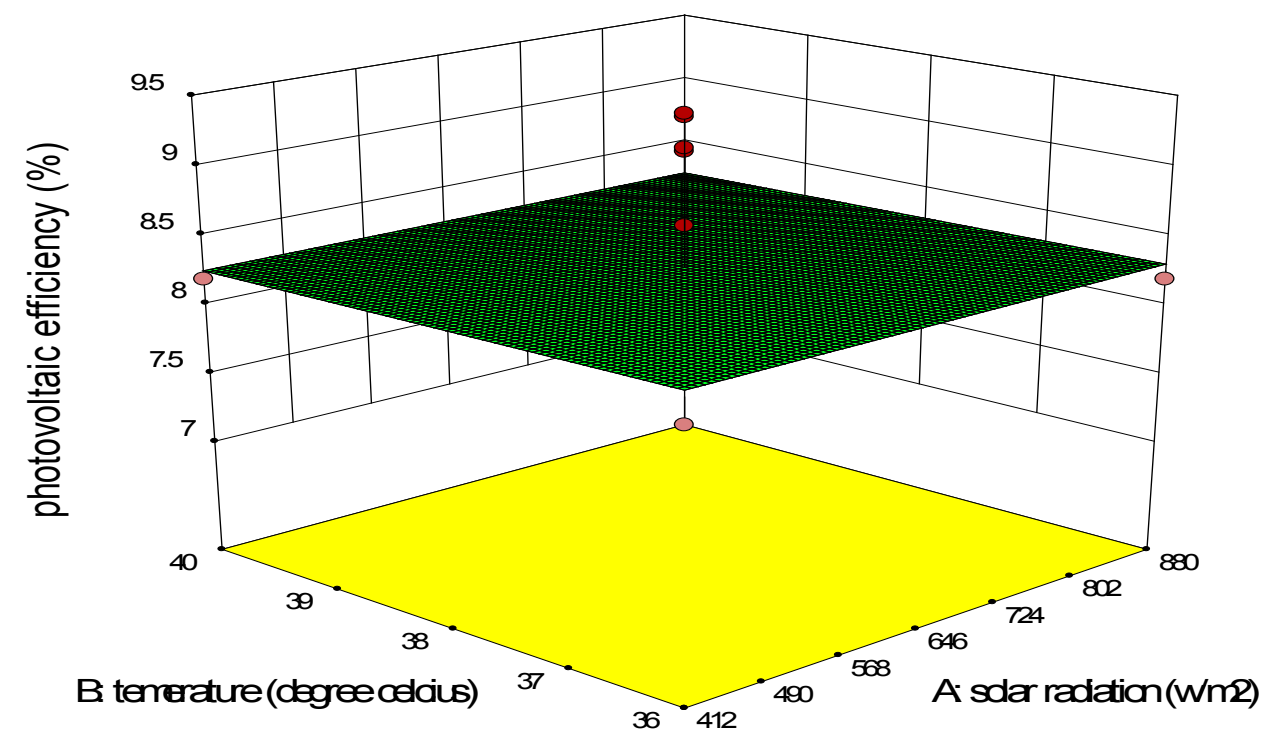

Figure 10. Analysis of photovoltaic efficiency with respect to solar radiation and temperature at full load (April) 


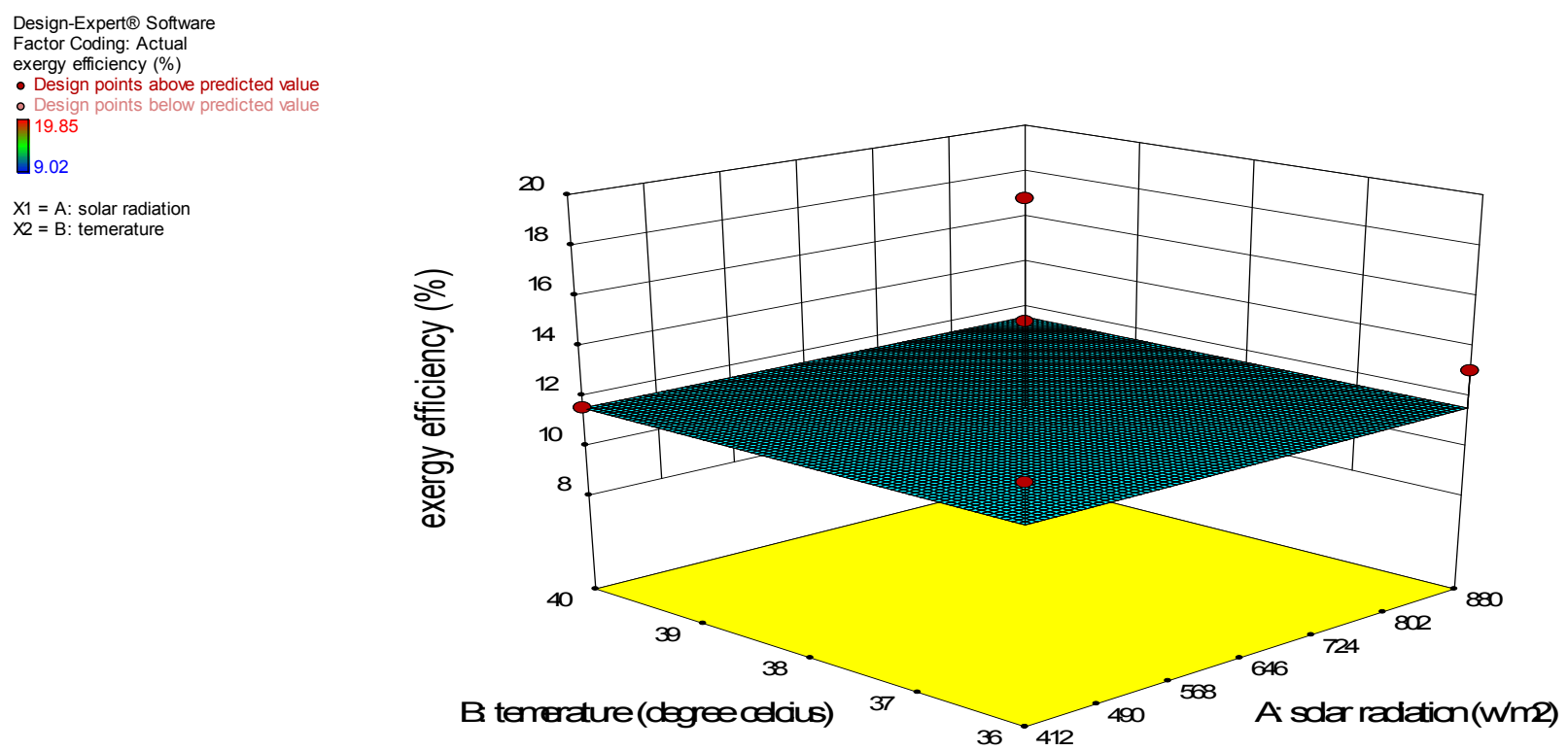

Figure 11. analysis of exergy efficiency with respect to solar radiation and temperature at full load (April)

\section{Conclusions}

Performance of photovoltaic system at no load and full load condition were carried out to assess its technical viability. This study indicated the necessity and usefulness of energetic and exergetic techniques to evaluate the performance of the SPV refrigerator. The average photovoltaic conversion efficiency and exergy efficiency found nearer to $8.5 \%$ and $11 \%$ respectively in both no load and full load condition for May month. This indicates that the full load condition does not affect the PV system. The photovoltaic and exergy efficiency was found less due to the module temperature hence exergy were destroyed highly in PV.

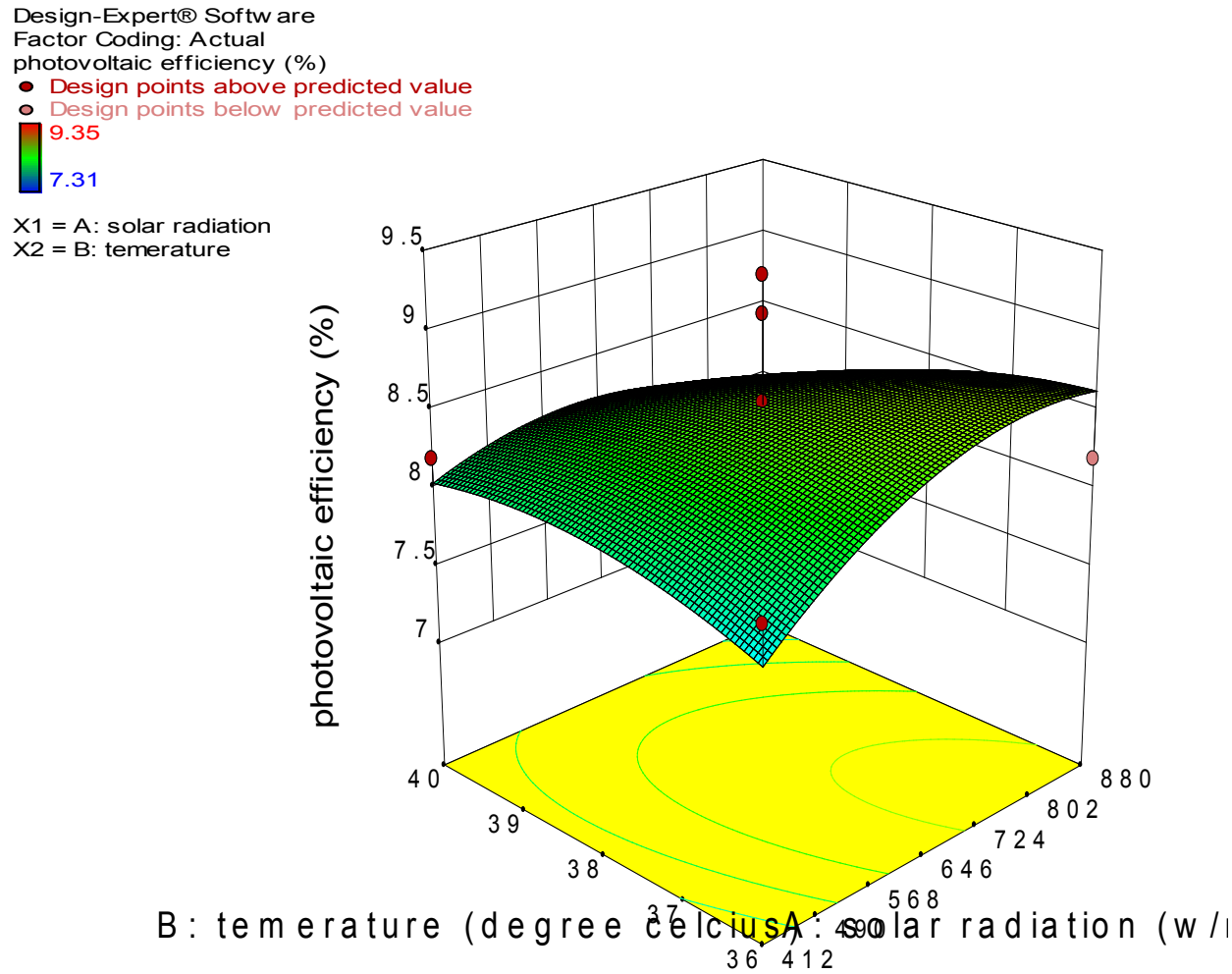




\section{Nomenclature}

DC - Direct current AC- Alternating current SPV - Solar photovoltaic PV- Photovoltaic W-Watt R-12 - Dichlorodifluoromethane $\psi_{\mathrm{PV}}$ - Exergy Efficiency $\mathrm{P}_{\text {output }}-$ Power output $\mathrm{Ex}_{\text {out }}-$ Exergy out $\mathrm{Ex}_{\mathrm{in}-}$ Exergy in

\section{REFERENCES}

[1] Charters, W.W.S. and Oo, Y.L. 2003.Solar vaccine storage units for remote areas. International Journal of Refrigeration, Vol. 10, 301-30.
[2] Eltawil and D.V.K. Samuel 2007. Vapour compression cooling system powered by solar PV array for potato storage. Agricultural Engineering International, The CIGR E Journal. Manuscript EE 06003, Vol. IX.

[3] Eltawil M.A. and D.V.K. Samuel. 2007. Performance and economic evaluation of solar photovoltaic powered cooling system for potato storage. Agricultural Engineering International the CIGR E Journal. Manuscript EE 07 008, Vol. IX.

[4] Fatehmulla A., Al-sharmmani and Al-Bassam (2011). Design of energy efficient low power PV refrigerator.. http://ipac.kacst. edu.sa/eDoc/2011/193687_1.pdf

[5] Yilanci A., E. Cetin and H. K. Ozturk 2011. Experimental Performance Evaluation of a PV-Powered Refrigeration System. Electronics and Electrical Engineering. - Kaunas: Technologija, 8(114), 7-10. 